\title{
高温加熱面の膜沸騰崩壊温度に関する研究 Study on Film Boiling Collapse Temperature of Hot Dry Surface
}

\section{正 大竹 浩靖(工学院大) ○学 永嶌 望(工学院大院) 正 小泉 安郎(信州大)}

Hiroyasu Ohtake, Nozomi Nagashima and Yasuo Koizumi

Kogakuin University, 2665-1 Nakano-machi, Hachioji, Tokyo 192-0015

Shinshu University, 3-15-1 Tokida, Ueda, Nagano 386-8567

The behavior of rewetting on a high superheated and dry surface, focusing on rewetting temperature just as collapse of saturated and subcooled film boiling was investigated experimentally and analytically. Saturated and subcooled impingement jet experiments were conducted by using a Silicon wafer with $20 \mathrm{~mm}$ length, 20 $\mathrm{mm}$ width and $0.5 \mathrm{~mm}$ thickness and pure water at atmospheric condition. Temperature of the test heater was measured by using a commercial separated-type infrared thermometer from a back side of it. The present experimental results showed that as the liquid subcooling was high, MHF temperature was higher. Namely, the experimental results agreed with Dhir-Purohit's correlation.

Key Words: Film Boiling, Minimum Heat Flux, Rewetting

1. 序論＼cjkstart鉄鋼の製造工程、特に金属組織の生成は、水冷 時の冷却特性と密接な関わりを持つ。多くの場合、この冷 却には沸騰現象を伴い、沸騰熱伝達の詳細な理解、特に高 温面上での濡れ開始条件の把握が必要である。これまで、 濡れ開始条件及び濡れの挙動、即ち膜沸騰崩壊条件と遷移

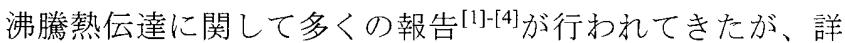
細な理解に至っておらず、未だ不明瞭な点が多い。本研究 では膜沸騰の崩壊条件の定量的把握として、水平上向き平 板を用いた液ジェットを衝突させ、高温加熱面上の濡れの 挙動を実験的に検討し、固液接触の温度条件及びその熱伝 達特性を得ることを目的とする。本稿では、特に赤外線放 射温度計を用いた非接触型の温度計測を試夕た。

2. 実験方法 Figure 1 に実験装置概要図を示す。本実験 装置は、(6)加熱面、(1)試験容器、(9)循環ポンプから構成さ れる大気解放のループ系である。試験液体には脱気した純 水を使用した。加熱面は厚さ $0.5 \mathrm{~mm}$ の Si ウェ八(熱伝導率: 約 $60 \mathrm{~W} / \mathrm{mK}, \mathrm{Bi}$ 数:約 0.0013 )を幅 $20 \times 20 \mathrm{~mm}$ に加工した薄 板であり、この加熱面はSUS303 製支持円盤に耐熱性セラ ミック接着剤で裏面から接着された後、水平上向きに試験 容器内部に固定される。以下に実験手順を示す。

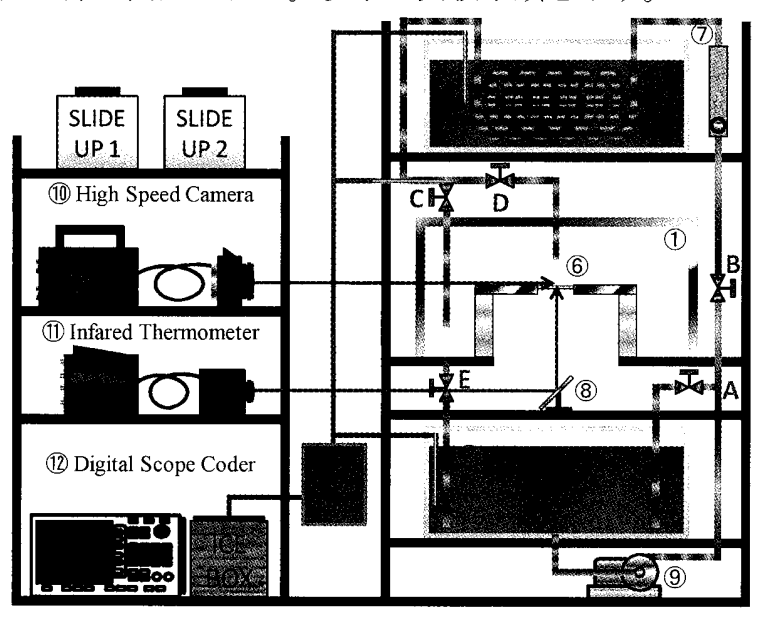

(1) Test Vessel (2) Main Tank (3) Sub Tank (4) Heater 1

(5) Heater 2(6) Test Plate (7) Rotameter (8) Mirror (9) Pump

Figure 1 Experimental Apparatus

(A) (2) Main Tank 内の (5) ヒータ 2 で試験液体を脱気後、 $100^{\circ} \mathrm{C}$ ま加熱する。

(B) (3)Sub Tank を所定の温度まで加熱した後、バイパス経 由で試験液体を循環させ、試験液体を所定の液温度、液流 量に設定する。この際、試験液体の液温度は(3)Sub Tank と
(4)ヒータ 1 を用いた間接加熱により調整し、試験液体の流 量は(7)浮子式流量計を用いて調整する。

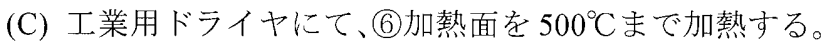
(D) バルブ D を開け、液噴流により加熱面を泠却する。こ の冷却時の加熱面の面温度分布を(8)市販の鏡を外位赤 外線放射温度計を用いて計測する。同時に、加熱面上の液 挙動を(10高速度カメラにて記録する。なお、面温度分布の 計測速度は最大 60 面/ $\mathrm{s}$ 、高速度撮影は最大 $3000 \mathrm{fps} に て$ 行 った。面温度分布の温度計測点は中心より $0 \mathrm{~mm} 、 2.11 \mathrm{~mm}$ 、 $4.22 \mathrm{~mm}$ の位置である。また、実験条件である液少ブクー ル度は $0 \mathrm{~K} \sim 40 \mathrm{~K}$ 、液流量は $0.29 \mathrm{~m} / \mathrm{s} 、 0.58 \mathrm{~m} / \mathrm{s}$ である。本実 験に使用した赤外線放射温度計の性能を Table 1 に示す。

Table 1 Performance of Infared Thermometer

\begin{tabular}{|c|c|c|c|}
\hline 測定温度範囲 & $-40 \sim 500^{\circ} \mathrm{C}$ & 空間分解能 & $1.5 \mathrm{mrad}$ \\
\hline 測定距離 & $30 \mathrm{~cm} \sim \infty$ & 温度分解能 & $0.05^{\circ} \mathrm{C}$ 以下 \\
\hline 視野角 & $26.4^{\circ}(\mathrm{H}) \sim 20.0^{\circ}(\mathrm{V})$ & 収録速度 & 最大 $60 \mathrm{frame} / \mathrm{sec}$ \\
\hline
\end{tabular}

3. 実験結果と考察 Figure 2 に、本実験により得られた 冷却曲線(温度履歴)の一例、赤外線放射温度による温度可 視化画像、高速度力メラによる液挙動画像を示す。この温 度計測に際し、放射率は 0.1 に設定した。Figure 2 に示す ように、冷却曲線及び液挙動画像より、膜沸騰期間、クエ ンチ点(急冷開始点、寸なわち膜沸騰最小温度)、急冷期間 が確認できる。Figure 2 より $\Delta \mathrm{T}_{\mathrm{sub}}=0 \mathrm{~K}$ 時に $413.12^{\circ} \mathrm{C}$ で確認 できた。Figure 3 に沸騰曲線の一例を示す。 $\mathrm{Bi}<0.1$ である ため、熱流束は集中熱定数近似を利用して求めた。

$$
q=\rho c \delta(\Delta T / \Delta t)
$$

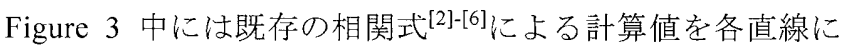
て併記した。Figure 3 に示すように、MHF 点温度は Dhir-Purohitの式に近いことが確認できた。

$$
T_{M H F}=201+8 \Delta T_{\text {sub }}
$$

定量的な一致が確認できなかったのは、温度計測点を中心 付近で行ったため液膜が進展する際の先端温度(スパッ夕 リング点温度)の計測ができなかったことが原因であると 考えられる。CHF 点温度も同様の理由で Ivey-Morris の相 関式と一致が確認できなかった。Table 2 に本実験により 得られた各液サブクール度と各液流速に対するクエンチ点 温度の結果を表にして示した。Figure 4 に本実験により得 られた各液サブクール度とクエンチ点温度の関係を示した。 また、Dhir-Purohit の式の計算值を直線にて併記した。 Figure 4 より液サブクール度の増加に伴いクエンチ温度が 
増加することが確認された。Figure 5 に各液流速とクエン チ点温度の関係を示した。クエンチ点温度の液流速に対す る依存性は確認できなかった。Figure 6 は液膜先端の移動 に注目し横軸に中心からの液膜先端の位置、縦軸に液膜先 端の温度を示したものである。蒸気膜を介して加熱面の温 度が減少し、濡れが周囲へと進展することが確認できた。 また、液サブクール度の増加に伴いクエンチ点温度が増加 することも確認された。
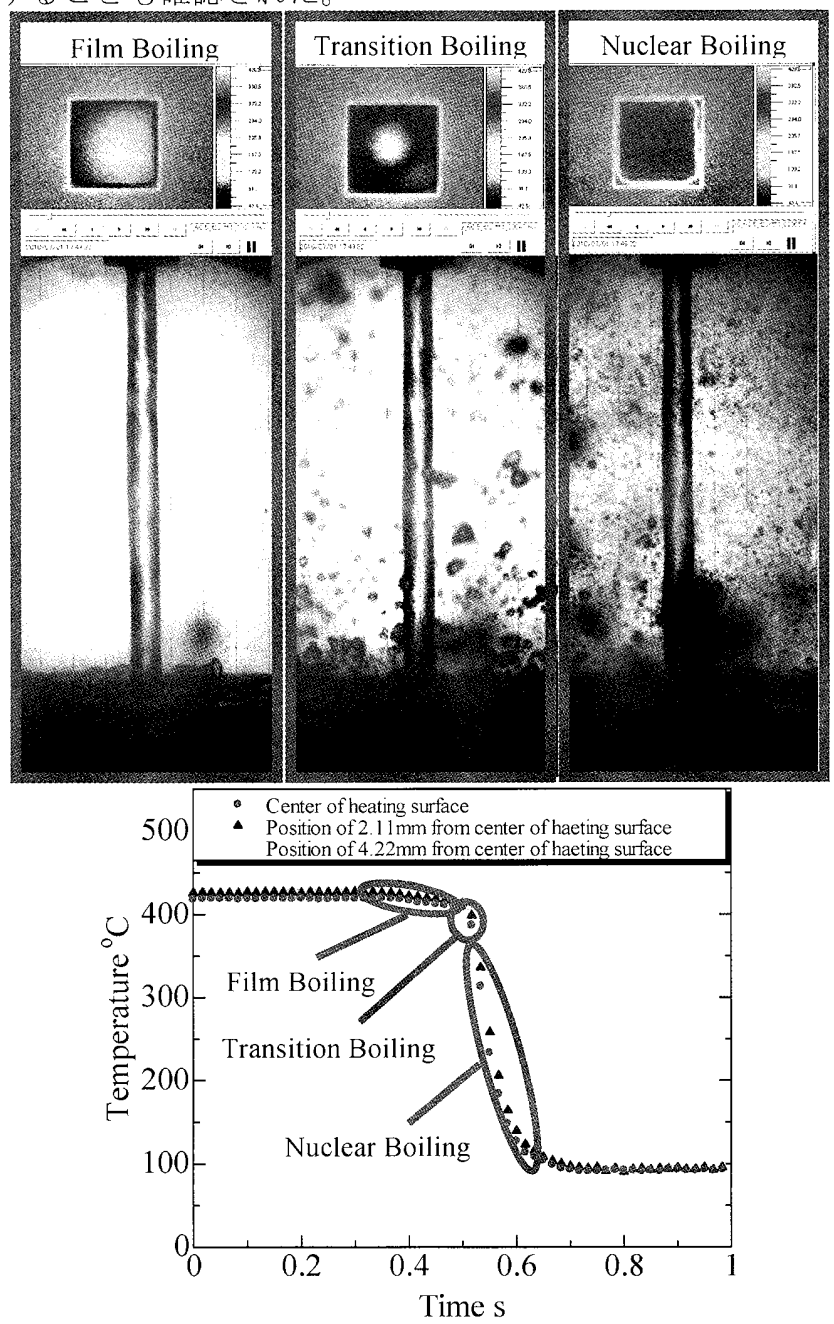

Figure 2 Cooling Curves, the behavior of rewetting and temperature distribution of area(Liquid Subcooling 0K, Liquid

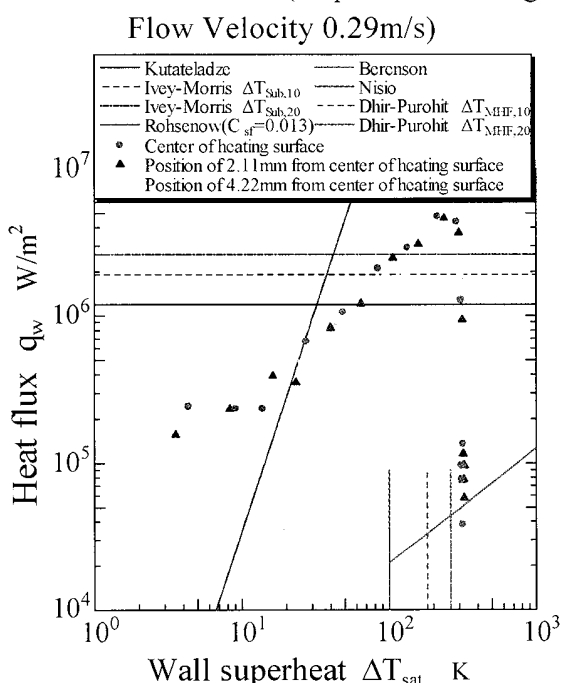

Figure 3 Boiling Curves(Liquid Subcooling 0K, Liquid Flow Velocity $0.29 \mathrm{~m} / \mathrm{s}$ )
Table 2 Quench point temperature(Minimum film boiling point temperature)

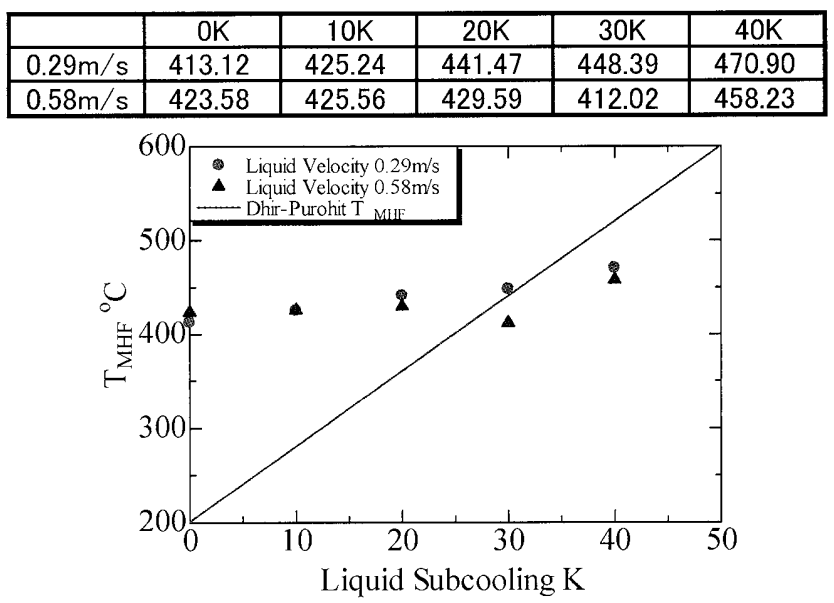

Figure 4 Correlation of liquid Subcooling and quench point

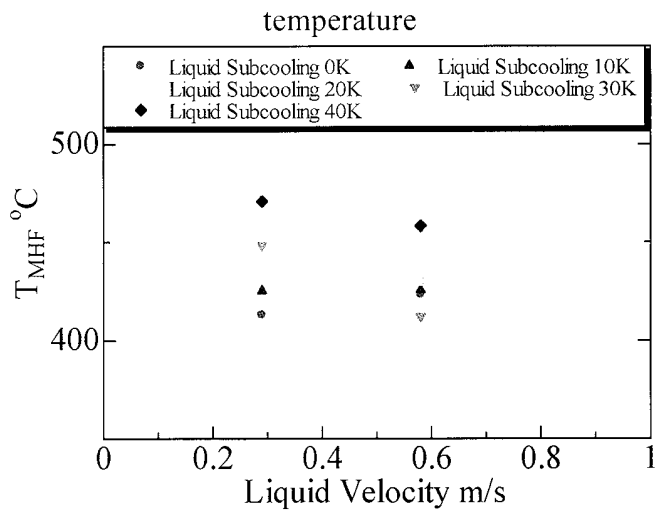

Figure 5 Correlation of liquid velocity and quench point temperature

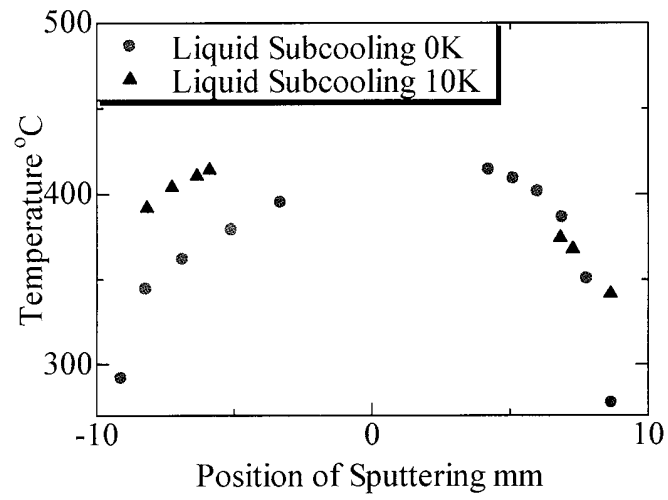

Figure 6 Position of sputtering temperature

4. 結論 赤外線放射温度計を用いた非接触の温度計測手 法により、高温過熱面上の面温度分布を計測し、膜沸騰崩 壊温度条件及びその熱伝達特性を検討した。前者は Dhir-Purohit の式に近いことを示した。クエンチ点温度に対 する各液サブクール度及び各液流速の依存性を検討し、サ ブクール度の増加に伴いクエンチ点温度が増加し膜沸騰期 間が短くなることが確認できたが、液流速の依存性は少な いことが確認できた。

参考文献 [1] 日本機械学会編, 沸騰熱伝達と冷却, (1989), 日本工業出版. [2] Dhir, V. K. and Purohit, G. P., Nucl. Eng. Des., 47(1978), 49. [3] Nishio, S., Int. J. Heat Mass Transf., 30-10(1987), 2045. [4] Ivey, H. J. and Morris, D. J., Rept. AEEWR 137, (1962). [5] Berenson, P. J., Trans. ASME, J. Heat Transfer 83, (1961), 351. [6] Rohsenow, W. M., Trans. ASME, J. Heat Transf., 74-3(1952), 969. 